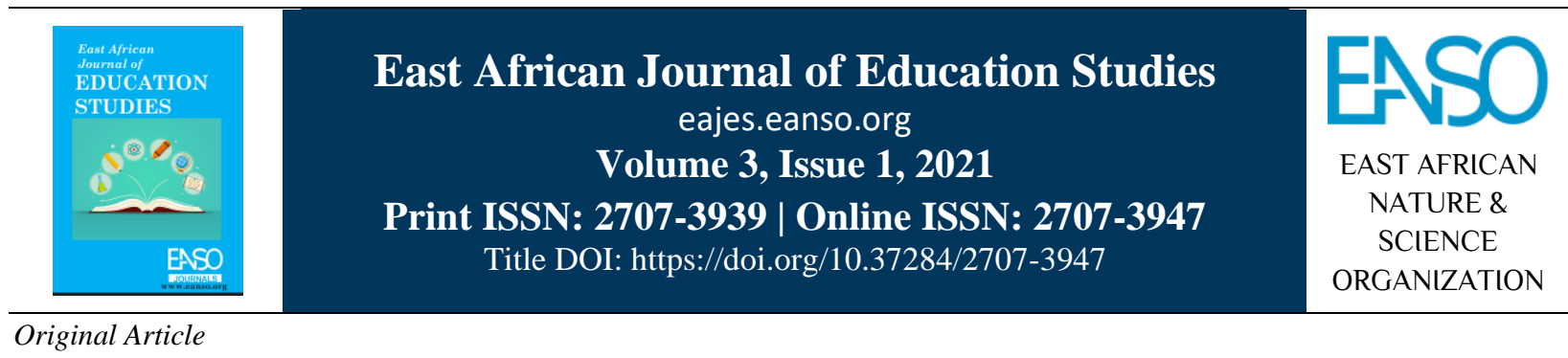

\title{
University Education and Values Re-Orientation for Socio-Economic Development in Nigeria
}

\author{
Dr. Stella Ofor-Douglas, PhD \\ ${ }^{1}$ University of Port Harcourt, PMB 5323 Choba, Rivers State, Nigeria. \\ Author Correspondence Email: stellaofor031@gmail.com.
}

Article DOI: https://doi.org/10.37284/eajes.3.1.389

\section{Date Published: ABSTRACT}

17 August 2021 This paper seeks to expound on the role of university education in promoting value orientation for socio-economic development in Nigeria. A quick examination of the

Keywords: terms of university education, value re-orientation and socio-economic development will be made in order to link how they lead to each other. With a

Education, comprehensive literature review, these terms will be viewed side by side with the University opinions of various scholars to offer expert opinions on their background. Education, University education is far more than just giving theoretical skills to students that

Values, will only be applied to their jobs in the future. Rather, the university environment Re-Orientation, can be used as a reservoir of value systems that can be passed to students so they Socio-Economic can have improved mindsets and lifestyles that work beyond a job. The objectives Development of this paper are to create an understanding of the ways that are possible to achieve national socio-economic development through the university system which should make a change in its previous methods by now emphasising the necessity of value re-orientation to impact the lives of students. Through this expected impact, youths will improve mentally, emotionally and build an industrious work ethic for more than just study-related matters. They will be able to contribute immensely to changes in the nation and step by step, the country can experience a turnaround in its socio-economic development. The importance of this effort will be highlighted and issues that hinder the discovery of this paper's goal will be deduced and allotted appropriate solutions applicable in real-life situations. Suitable suggestions will be made to give a reader practical knowledge on how to sustain the solutions provided in this paper.

\section{APA CITATION}

Ofor-Douglas, S. (2021). University Education and Values Re-Orientation for Socio-Economic Development in Nigeria. East African Journal of Education Studies, 3(1), 211-222. https://doi.org/10.37284/eajes.3.1.389.

211 This work is licensed under a Creative Commons Attribution 4.0 International License. 


\section{CHICAGO CITATION}

Ofor-Douglas, Stella. 2021. "University Education and Values Re-Orientation for Socio-Economic Development in Nigeria". East African Journal of Education Studies 3 (1), 211-222. https://doi.org/10.37284/eajes.3.1. 389.

HARVARD CITATION

Ofor-Douglas, S. (2021) "University Education and Values Re-Orientation for Socio-Economic Development in Nigeria", East African Journal of Education Studies, 3(1), pp. 211-222. doi: 10.37284/eajes.3.1. 389.

\section{IEEE CITATION}

S. Ofor-Douglas, "University Education and Values Re-Orientation for Socio-Economic Development in Nigeria”, EAJES, vol. 3, no. 1, pp. 211-222, Aug. 2021.

\section{MLA CITATION}

Ofor-Douglas, Stella. "University Education and Values Re-Orientation for Socio-Economic Development in Nigeria". East African Journal of Education Studies, Vol. 3, no. 1, Aug. 2021, pp. 211-222, doi:10.37284/eajes.3.1.389.

\section{INTRODUCTION}

University education is very important to the lives of youths seeking to create sustainable futures for themselves. These youths must therefore acquire the necessary skills needed to obtain jobs or create those jobs for themselves. University education does not only encompass teaching to acquire jobs, but it also creates an avenue for students to procure values or get a renewed sense of values already known so that an individual can apply to improve himself and lifestyle. It is important to understand what this activity of value re-orientation entails and how to capture it effectively. The demand for increased and improved management of education has never been greater and now more than ever, we need management professionals who are also to combine ethical ways of operating into effective ways of achieving results (Tienhaara, Lyytineen and Kivisto, 2016). These values contribute positively to the lives of individuals and to the development of Nigerian society as a whole. A university is a model example for students and the values they learn therein will help them grow in society. The Nigerian educational system is lacking in its re-orientation of values and economic development. This paper fills in the need to have values re-orientation for socioeconomic development. That is why this study is being carried out. There are issues bordering on university education and value re-orientation for socio-economic development that beg for answers. That is why the researcher is carrying out this work to fill the missing knowledge gap on university education and values re-orientation for socioeconomic development in Nigeria. Therefore, the following subtopics will be discussed accordingly. The missing gap in university education and values re-orientation for socio-economic development in Nigeria is the actualisation of the values which should be incorporated for socio-economic development in Nigeria.

\section{EDUCATION}

Education is the only weapon to inculcate the right types of values, norms in our youths and citizens in the society and the nation for political, cultural, and socio-economic development. The word education is derived from the Latin word "edu-care", which means to" bring up", "lead out", "raise", or "elevate". Education is a huge determinant of the economic and social development of a nation. It is imperative to understand its value and what it contributes to the lives of people. 'The education system of any economy performs these main tasks: first, it handles the basic and higher education; second, it provides better opportunities of income; third, it enhances the living standard and helps in social development' (Misra, 2012). Education is vital to socio-economic development and should be promoted and encouraged to increase a nation's development. 'Higher levels of literacy lead to greater economic output, higher employment levels, better health, better social structures, and a number of other development indicators' (Misra, 2012).

Ikegbusi and Ezimamaka (2016) cited in Muhammad, Aliyu and Kwazo (2017) states that teachers teach, train, and assist students to acquire the necessary life skills that would enable them to survive and contribute meaningfully to the society they belong to. Adepoju and Fabiyi as cited in Ekpo and Ish'ak (2014) view education as a weapon for acquiring skills, knowledge, and competence for survival in a changing world. Olawaiye (2013)

212 | This work is licensed under a Creative Commons Attribution 4.0 International License. 
remarks that education is the process of acquiring knowledge, skills, attitudes, interests, abilities, competence and cultural norms of society by people and transmitting life to the coming generations so as to enhance the perpetual development of the society.

In the same vein, Ademowo and Balogun (2014) mentioned that education is a means through which the individual acquires the desired norm, attitudes, values, skills, and knowledge needed for a useful and fruitful life for the progress of society, without minding whether it is formal, non-formal or informal. Also, Hamidu (2013) noted that education is the complete mental and physical transformation of a person(s) because of the structured model of training that the person(s) acquires to be productive in each society. Similarly, education is a personality building process that had been linked with society (Santhi, 2016). Santhi (2016) observed that education without value is useless. One cannot be educated and lack values; values help in shaping an individual to be a better person in society. Chidili (2019) reasons that education is the deliberate, systematic, and sustained effort to transmit, evoke, or acquire knowledge, attitudes, values, skills, or sensibilities as well as other outcomes of that effort. It involves the all-around development of an individual physically, socially, morally, and intellectually

Agwu and Dorgu (2015) indicate that education is an instrument for economic, political, social, and technological development. The implication is that education is what a nation uses to drive the vehicle for economic, political, social, and technological developmental strides. Mezieobi (20132) posits that education is proper schooling motored exposure of the students' clientele to a learning process in which the learners learn or are guided to learn relevant knowledge, information, skills, values, attributes and are imbued with the critical creative, perceptual and participative abilities that would enable them to be content and quite functionally successful with their life problems and challenges and usher in the interest of correct sustainable social living and the nation. As surmised by Taiwo (2012) cited in Kpolovie (2012), education is a lifelong process that has interpretation in purpose, type, and level. Okafor (1981) views education as a process of acculturation through which the individual is helped to attain the development of his potentials and their maximum activation when necessary, according to the right reason and to achieve his perfect selffulfilment. Also, in the same vein, Muhammad et al. (2017) opine that education is widely accepted as a major instrument for promoting socio-economic, political and cultural development in Nigeria.

Duru (2011) sees education as comprising all the series of instructions and discipline which is intended to enlighten the understanding, correct the temper, and form manners and habits of youths and fit them for usefulness in their future stations. Olayanju (2014) maintains that education plays a critical role in human capacity building to have bright future needs to emphasise education because it is the only way to develop and the best legacy a nation can give to its citizens. Enaigbe and Igbinoghene (2016) remark that education is the prerequisite for a successfully engineered national system and is the answer to ignorance and servitude, the gateway to the future and the key to national development.

Lawal (2013) posits that education is an instrument for self-reliance, social reconstruction, and economic development. Also, Omoregbe (1989) is of the opinion that to educate a person in mind and not in morals is to educate a menace in society. Asiru (2014) comments that education is a catalyst to the development of individuals, society, and the nation. Education can also be that process through which portions of knowledge are gained and skills, attitudes and values acquired so that people can function properly in society. Adekola (2016) posits that education is the basis and foundation for ethics, values, norms, human interaction, individual, community and national development (Obilo and Opara-Onukwugha, 2008).

Education is perceived as the process of imparting knowledge, skills, and development of the moral character of an individual. Its pivotal aim is to make an individual learn how to live with society by developing intellect, equipping oneself to deal with the reality of life and but facilitating the realisation of self-potential and latent talent of an individual. Haruna and Liman (2015) remark that education is an instrument for national development and social change as well as building an individual into becoming a functional and acceptable member of society. Akpo (2015) noted that education is the 
process of facilitating knowledge through the transfer of skills, values, beliefs, and habits under the guidance of educators though the learners may also educate themselves in a process called autodidactic training. Education is a personality building process that had been linked with society (Santhi, 2016).

Duyilemi (2016) cited in Ofor-Douglas (2019), stating that education involves the transmission of what is worthwhile or what a particular society values so highly that it finds important to pass on to each succeeding generation, the aim is concerned with schemes and objectives is concerned with gains and achievements. To develop the capacity to learn, acquire knowledge and skills that are essential for the transformation of individual and national values, there is a need for learners to imbibe socially acceptable behaviours and positive habits that are necessary for the development of self and the Nigerian society (Oluwagbohunmi, 2013). Egwu in Iyiagu (2014) observes that human resource development through well-planned education and training initiatives can contribute significantly to promoting the interest of individuals, enterprises, the economy and society within the nation. The above authors have noted salient factors of education that should not be dismissed in any society. Education has the power to transform situations, people and societies for their betterment. Therefore, education is consequently a tool for societal change.

\section{UNIVERSITY EDUCATION}

Higher education is a level of education offered after secondary education in dedicated institutions such as universities, colleges of education, polytechnics, monotechnics and other allied and specialised institutions (Modebelu and Joseph, 2012). Higher education is usually sought-after secondary education to obtain knowledge and skill to pursue a position in the workforce. University which is part of higher education is said to be built on the level of competence, knowledge and skills normally acquired in secondary education (Anyanwu, 2020). Higher education plays a crucial role in the supply of high-level manpower for the socio-economic development of a nation (Castell, 1998). The university is a community of scholars and students engaged in a complex task of learning to which humanity looks up for overall human progress (Robert-Okah and Daminabo, 2014). Acquiring a university education is a big step to assist ambitious individuals to achieve change in their country. University Education is education acquired after secondary school. The aim of university education is to train manpower who will man the sectors of the economy for productivity gain in the country.

\section{Values}

Enu and Esu (2011) remark that values are basic beliefs and attitudes in a society of individuals or groups which are considered worthwhile and serve as a guide to choices and behaviour in our daily life. A value can, therefore, be a belief system that attempts to guide an individual's actions in life. To develop the capacity to learn, acquire knowledge and skills that are essential for the transformation of individual and national values, there is a need for learners to imbibe socially acceptable behaviour and positive habits that are necessary for the development of self and the Nigerian society (Oluwagbohunmi, 2013). It is imperative for universities to adopt values in their curriculum to ensure there is a positive impact on students' lives which they can live with after university education.

Jen and Jonathan (2010) as cited in Frank-Oputa and Soberekon (2021) categorise values into the following types:

- Personal Values: These represent things individuals considered more important than every other thing in their lives.

- Personal values: These values help individuals to determine what is right and wrong.

- Political Values: These values are used to evaluate social institutions.

- Aesthetic Values: These values are associated with the evaluation of artwork.

The school is a model of the world, so the goal of value-based education is to nourish the learner with moral values and virtues on which their actions will be based. Rokeach (1973) as cited in Tuulik et al. (2016) views values as an ending belief, a specific mode of conduct or an end state of existence, along 
with a continuing of relative importance. Values are present in every culture. They are important for the fostering of group existence, harmony and the production of group welfare. Honesty, integrity, truth, obedience, loyalty, kindness, and chastity are examples of values that are necessary to ensure social integration, development, and transformation. People's goals in life are usually defined in terms of the value system of society (Okobia, Okafor and Osajie, 2016; Frank-Oputa and Soberekon, 2021).

\section{Importance of Value Education}

It is essential for a university to provide value to its students for several reasons. Some of such reasons are opined by Paul (2020), who remarks that the neglect of teaching moral values in schools is hurting our students and causing problems in society. Hence, he advocates the teaching of values in our schools for the following reasons:

- Preparing our children for future roles in society.

- Many parents are not teaching moral values at home.

- There is too much violence and dishonesty in society.

- To counter bad influence in society.

- Moral values will stick with an individual for life.

It is of the essence that values are taught alongside the standard curriculum in universities because the lack of these values will result in a detrimental effect on the lives of students and a stunt to societal development. Rokeach (2018) views value as an ending belief, a specific mode of conduct or an end state of existence, along with a continuing of relative importance. Nielsen (2005) comments that values influence a person's choice of action, pursuits, and responses to issues. Anzene (2014) views values as deep-sealed beliefs that influence people's actions and behaviour. Values orientation is the process of directing the interest and passion of individuals to the desired socio-cultural values that promote social development and good human relations. Values are present in every culture. They are important for the fostering of group existence, harmony and the production of group welfare. Honesty, integrity, truth, obedience, loyalty, kindness, and chastity are examples of values that are necessary to social integration, development, and transformation. People's goals in life are usually defined in terms of the value system of society (Okobia, Okafor and Osajie, 2016; FrankOputa \& Soberekon, 2021).

Nwoko and Kpee (2018) see values as those qualities that regulate and guide human behaviour and actions in day-to-day living which may include honesty, loyalty, social justice, self-control, goodness, rightness. Enu and Esu (2011) maintains that values are basic beliefs and attitude in a society of individuals or groups which are considered worthwhile and serve as a guide to choices and behaviours in our daily life, Chukwuebuka (2013), sees values as something that constantly reflects a people's daily lifestyle. Ojo and Abibu (2018) view values as acceptable standards and the ideal way of doing things while living virtuously in life in society. To develop the capacity to learn, acquire knowledge and skills that are essential for the transformation of individual and national values, there is a need for learners to imbibe socially acceptable behaviours and positive habits that are necessary for the development of self and the Nigerian society (Oluwagbohunmi, 2013). Unamba, Izuagba and Ogbonnaya (2016) see values as those things that are morally right which could differ from community to community. Uko (2014) comments that there has been a general outcry about the poor quality of the educational output in the country. Igbuzor (2013) views values to be beliefs that influence people's actions and the rules by which they made decisions within their society. He went further to observe that values determine actions which in turn influence behaviour. They are driving forces that enhance positive development.

Magaji (2014) indicates that useful knowledge and skills are the core values upon which any form of education worthwhileness is assessed. It seems that those core values are missing in Nigeria's education system at present; this can be discerned from inadequate funding of schools, dilapidated infrastructures, and shortage of qualified teachers, which have resulted in poor teaching and learning, poor quality graduates, high rate of youth unemployment, rising crime rate and insecurity in 
the nation. Achuonye and Ajoku (2003) posit educational values of learning to include arousing curiosity and awakening discovery, fostering a sense of responsibility, and enhancing cooperative spirit. Mezieobi (2013) state that values are the desirable behaviour and perceptions of a group of people which are acquired and shared by members. Dimkpa (2017) emphasised that the extent to which morals have decayed and the subsequent loss of values in the Nigerian educational system are riddled with lots of ills and shortcomings, especially from the post-independent era till now.

\section{Lack of Value in the Society}

In Nigeria today, values have been disregarded immensely. This has resulted in societal dilemmas with vices such as exam malpractice, corruption, cultism etc. (Orji and Umoren, 2016). (2017) states that declining values in our educational system are the results of globalisation, materialism, commercialisation of education, environmental degradation, violence, terrorism, etc.

\section{Re-Orientation}

The term re-orientation could come in two senses as seen in Audio English Dictionary (2021) and they are 'a fresh orientation; a changed set of attitudes and beliefs play and the act of changing the direction in which something is oriented'. Re-orientation is the act of changing, adjusting, aligning, or realigning something in a new or different reaction. (Osisioma, 2012). Re-orientation can therefore mean an action to change, renew or reform people's beliefs to another. Re-orientation of values is essential, and the right values should be spread to the individuals and groups in a society. This is because of how to value orientation can transform a society. As submitted by Adagba (2014) cited in Anurugwo (2019), ethical re-orientation aims at raising the consciousness of the citizenry and politicians to see the sacred nature of education rather than making isolated attempts at turning around a particular institute or university. Anurugwo (2019) posits that value re-orientation entails the sensitisation of Nigerians in respect to positive values that will engender harmonious living, progress, and development of the nation. Value re-orientation is aimed at repositioning or decolonising the mindset of Nigerian citizens from negative perceptions and practices to a more positive mindset or perception to issues and ways of doing things rightly at all costs to bring about sustainable national development. Kaura in Asuju, Arome and Mukaila (2014) opine that value orientation is the process of providing awareness of one's temporal, practice, or circumstantial condition of the social values which at the end should result in behavioural modification. Njoku (2015) maintains that Nigerians do not need to look for new ways of behaviour rather re-orientation of the positive values that have once sustained the Nigeran public and private sectors. Dienye and Iwele (2011) indicate that values orientation entails influencing people to adjust, turn to or conform to specified values needed by the society.

\section{Values Re-orientation}

Value re-orientation is conceptualised as the act of deliberately attempting to change the direction in which attitudes and beliefs in Nigeria are currently orientated or the act of adjusting or aligning behaviour, attitudes and beliefs of Nigerians in a new or different direction within the public discourse of contemporary Nigerian politics" (Osisioma, 2012). Value re-orientation is a conscious attempt to reform the values of an individual or group of persons in alignment with a goal usually meant to further positive change. Njoku (2015) sees value re-orientation as inculcating good values that can help Nigeria out of her numerous predicaments and can refocus the nation through greatness. Value re-orientation is an effective means to bring about transformation in Nigeria and prevent situations that have brought the country down from occurring again. Value re-orientation can be achieved through the university system, which can serve as a tool to make students' lives in and outside of the university beneficial to themselves and the society.

\section{Socio-Economic Development}

This may refer to the transformation of society with regards to social and economic dimensions. Socialeconomic development incorporates public concerns in developing social policy and economic initiatives. Hence, socio-economic development can be described as any means to ensure the growth and sustainability of the social and economic areas 
of a nation. The ultimate objective of social development is to bring about sustained improvement in the well-being of the individual, groups, family, community, and society at large. It involves a sustained increase in the economic standard of living of a country's population, normally accomplished by increasing its stocks of physical and human capital and thus improving its technology.

Socio-economic development is purposed in ensuring the standard of living in a nation is high and can be sustained. Taken from the quote by Julius Nyerere cited by Ihejirika and Ogbugo (2018) submitted that development is the improvement of man by man and for man. This implies that the purpose of development is the improvement of man first, which must be directed to the fulfilment of human potentials and the advancement of the social and economic well-being of the people. The result of development is for the better improvement of man to a state of comfortable being. Nzeneri (2013) states that any development that is not centred on mans' needs, socio-economic life, political, cultural, and spiritual life is meaningless and stands as a barrier to national development that can be sustainable. Ihejirika and Ogbugo (2018) upheld that a country cannot be said to have developed until the rural communities in a country are developed and integrated into the national development.

\section{Advantages of University Education to Socio- Economic Development}

- University education provides a curriculum that encourages creativity and independence for students which they can apply after university level in socio-economic development.

- It allows a student to develop skills beyond the norm so they can go across national borders.

- It increases a student's chances of adapting to the socio-economic aspects of society based on their field of study and contributing to it.

- It helps students develop a good, hard-working, goal-oriented lifestyle which helps them in the workforce.

\section{RELATIONSHIP BETWEEN UNIVERSITY EDUCATION, VALUE ORIENTATION AND SOCIO-ECONOMIC DEVELOPMENT}

After an examination of the above terms, one must understand how their combination will result in socio-economic development in Nigeria. Olasehinde-Williams 2018) opines that education provides recipients skills for economic resources to enable them to conquer poverty, as well as social skills for forging efficient relationships with other members of the society. Similarly, Western or formal education has the potential to transform and empower individuals and, by extension, communities or societies (Nwogu, 2013). University education is important to the development of individuals future. Applying value orientation to university education leads to easy dissemination of values to students. As a result of participating in value orientation sessions in university, students can then apply these values to contribute to socio-economic development. This process will lead to a decrease in the crime rate on the part of youths and it will also ensure youths adequately participate in activities that will benefit their society.

\section{Objectives of University Education and Values Re-Orientation for Socio-Economic Development in Nigeria}

The topic of this paper has some objectives it intends to achieve, and they are as follows:

- To create an easy understanding of this paper's topic.

- To identify the ways the paper's topic can be achieved.

- To show the necessity of teaching value orientation in universities.

- To encourage conversation on this topic and promote others to contribute to awareness and research of it. 


\section{Issues Plaguing University Education and Values Re-Orientation for Socio-Economic Development in Nigeria}

- No priority on university education by the Nigerian government which means most public universities will not be standard for students.

- Lack of global competitiveness of universities in Nigerian. This means Nigerian universities will not grow according to the evolution of international universities but remain idle in their development.

- Inadequate funding of universities: without adequate funding of universities in Nigeria, they cannot introduce new programmes or obtain facilities that support or boost value orientation for students. The financial challenge facing University education in Nigeria is gross underfunding, which could be linked to undue reliance on the government for funds by university management (Ofoegbu and Alonge, 2016).

- Limited staff to student ratio: the staff in universities are not sufficient for the large student capacity, which means all students will not receive adequate attention from lecturers if they need it.

- Brain drain: The number of Nigerian students who go abroad to study or work reduces the numbers that would have contributed to socioeconomic development in Nigeria.

- The inability of University education to produce adequate manpower with required knowledge, skills, and values for effective nation-building. This means many graduates do not possess the skills they claim to have studied in university. As a result, there will be mostly inexperienced or unskilled graduates seeking jobs and they will not adequately contribute to socio-economic development (Olasehinde-Williams 2018)

- Lack of quality facilities, the curriculum in universities in Nigeria. (Olasehinde-Williams 2018)

\section{CONCLUSION}

This paper has been able to highlight the necessity of value re-orientation to Nigerians. By making value re-orientation available at higher institutions, it is a good way to ensure a wide range of students obtain sound morals and discipline that will help them contribute to society immensely. If applied diligently, value orientation in a university education will lead Nigerian youths to apply themselves more positively to socio-economic development. Therefore, the advantage of value orientation will ensure the continued welfare of the Nigerian society and reduce social vices. That desired state of the nation will only be achieved by the actions of various parties, namely the government, university administrations and students. If every university implements value reorientation in their curriculum, more students will have a better chance at living a positive lifestyle after university.

\section{Suggestions}

After an examination of the issues mentioned above, the author has proposed suitable suggestions applicable in real-life situations. These are as follows:

- The Federal government should include value orientation in every university's curriculum so students can develop skills and values that will help them contribute to the society positively.

- The collaboration of the government, university stakeholders, university administration boards and students must be ensured so value orientation is made possible and sustainable.

- Various means of practicalising the values students have learned should be organised.

- Assessment of skills obtained during value orientation should be made available for students in universities.

- Facilities to promote value re-orientation should be organised and made available for students in every university.

- Seminars, club meetings, workshops, events focused on value re-orientation should be

218 This work is licensed under a Creative Commons Attribution 4.0 International License. 
organised by the university to encourage students to partake in.

- Different organisations, whether governmental or non-governmental, should organise programs to assist youths in acquiring skills and values.

- Universities should adopt courses that focus on value re-orientation so students can specialise in them.

- A conducive learning environment should be made available.

- The management and staff should serve as role models to the students.

- The area of community service participation by students should be implemented to the latter, where one of the goals of university education is to serve as a partaker of community service and development.

- We need to go back to the basic value education to have proper value re-orientation in the university system to produce well-groomed graduates to the labour market and the society at large.

\section{REFERENCES}

Achuonye, K. A., \& Ajoku, L. I. (2003). Foundations of Curriculum Development and Implementation. Port Harcourt: Pearl Publishers.

Adekola, G., \& Egbo, N. C. (2016). Traditions and Customs in Community Development: The Case of Nkanu West and Nkanu East Local Government Areas of Enugu State, Nigeria. Journal of Education and Practice, 7(18), 120-127.

Ademowo, A. J., \& Balogun, N. (2014). Proverbs and conflict management in Africa: A study of selected Yoruba proverbs and proverbial expressions. International Journal of Literature, Language and Linguistics, 1(1), 1-7.

Agwu, S. N. \& Dorgu, T. E. (2015). Towards effective teacher education for proper implementation of the secondary education curriculum in Nigeria. Nigerian Journal of Curriculum Studies, 22 (3) $33-47$.

Akpo, B. (2015). Education for emotional balance. Educational fitness for sustainable development in Nigeria. Rapid Educational Publictions.

Anurugwo, A. O., \& Mbara, K. U. (2019). Andragogical Principles in Farmer Education: Implications for Rural Extension Agents. JCCR Journal of Community \& Communication Research, 4(2), 79-87.

Anyanwu, J., \& Ewhe, J. E. (2020). Governance Issues in Higher Education in Nigeria. European Journal of Education Studies.

Anzene, S. J. (2014). The challenges of value reorientation in Nigeria's tertiary education system. Mediterranean Journal of Social Sciences, 5(14), 221-221.

Asaju, K., Arome, S., \& Mukaila, I. (2014). Leadership crisis in Nigeria: The urgent need for moral education and value re-orientation. Public administration research, 3(1), 117.

Asaju, K., Arome, S., \& Mukaila, I. (2014). Leadership crisis in Nigeria: The urgent need for moral education and value re-orientation. Public administration research, 3(1), 117.

Asiru, T. A. (2014). Primary education and national development in Nigeria. International journal of special and general education, 3, 155-165.

Audio English. (2021). Re-orientation. https://www.audioenglish.org/dictionary/reorien tation.htm\#: :text=1.,in\%20which\%20somethin $\mathrm{g} \% 20$ is\%20oriented

Castells, M. (1998). End of Millennium. The Information Age: Economy, Society. Culture, 3, 5-24.

Chidili, B. (2019). Transforming religious communities through the virtue of justice. The Catholic Voyage: African Journal of Consecrated Life, 11.

Chukwuebuka, C.A. (2013). Rebuilding the Nation's Foundation: Fostering National

219 | This work is licensed under a Creative Commons Attribution 4.0 International License. 
Integration and Security through value reorientation. Paper presented at the $I^{\text {st }}$ National South East Zonal Conference of Colleges of Education held at Alvan Ikoku Federal College of Education October 2012.

Dienye, V. U., \& Iwele, M. U. (2011). Education for value orientation in a multicultural society: The case of Nigeria. African Journal of Education and Technology, 1(3), 40-44.

Duru, V. N. (2011). Curriculum Studies Concepts, Development and Implementation. Owerri: Avan Global Publications.

Ekpo, C. G., \& Is'haq, A. B. (2014). Education and transformation agenda in Nigeria: An appraisal. Journal of education and practice, 5(8), 83-90.

Enaigbe, P., \& Igbinoghene, N. (2016). Challenges of managing and planning peace education and peace culture in Nigeria. African research review, 10(4), 83-92.

Enu, D. B., \& Esu, A. E. O. (2011). Re-Engineering Values Education in Nigerian Schools as Catalyst for National Development. Internation al Education Studies, 4(1), 147-153.

Frank-Oputa, E.A., Soberekon, W.S. (2021). Values Education: An essential tool for the transformation of Contemporary Nigerian Society. In (Ed) Maliki, A. E, Agih, A. A, Adeyinka, A. A., Dimkpa, D. I. \& Paulley, F. G., Managing Educational Transformation in Contemporary Nigeria. A Book of Readings in Honour of Professor Tawari,T.O. (pp. 214-220).

Hamidu, I. (2013). Students Poor Performances in Nigeria: Critical Issues: Effects, Problems and Prospects. International Journal of Social Science \& Sustainable Development, 3 (2).

Haruna, M. J., \& Liman, B. M. (2015). Challenges facing educating Nigerian child in rural areas: Implications for national development. Proceed ing of the 3rd Global Summit on Education, Kuala Lumpur, Malaysia.https://worldconferen ces.net/proceedings/gse2015/paper\%20gse15/G , 20088.
Igbuzor, O. (2013). Value re-orientation and transformation: A panacea for growth and development. In A Paper presented at the 2013 Conference of the Institute of Strategic Management, Nigeria, FCT Chapter.

Ihejirika, J. \& Ogbugo, E. (2018). Influence of Traditional Rulers in Resource Mobilization Towards Community Development Projects in Rivers State. International Journal of Innovative Psychology \& Social Development, 6 (2), 98112.

Kpolovie, P. J. (2012). Education reforms without evaluation designs: Nigeria at risk. Springfield Publishers Limited.

Lawal, Y. O. (2013). Education as an instrument for effective national development: Which way Nigeria. Business \& Entrepreneurship Journal, 2(2), 27-38.

Mezieobi, K. A. (2013). Nigeria's Full Sovereignty: Which is Prepondering Good or Bad Governance. Journal of Multidisciplinary Social Discourses, 8 (4).

Misra, S. (2013). Contribution of education in the socio-economic development: an empirical study. Logos, Universality, Mentality, Education, Novelty. Section Social Sciences, 2(1), 369-395.

Modebelu, M. N., \& Joseph, A. (2012). Strategic planning procedure: An imperative for effective management of higher education in Nigeria. Mediterranean Journal of Social Sciences, 3(15), 20-20.

Muhammad, U., Aliyu, U. A. \& Kwazo, L. A. (2017). Funding as a tool for Revitalizing University Education for Social Political and Economic Engineering in Nigeria. International Journal of Topical Educational Issues, 1 (2), 269 $-282$.

Nielsen, T. W. (2005). Values education through thinking, feeling and doing. Social Educator, 23(2), 39-48.

Njoku, D. I. (2015). Re-orientation of value system in Nigeria: A critic. Global Journal of Arts, Humanities and Social Sciences, 3(11), 25-32.

220 | This work is licensed under a Creative Commons Attribution 4.0 International License. 
Nwogu, G. A. I. (2013). Education and national development in Nigeria: A philosophical perspective. African Research Review,7(2), 266-276.

Nwoko, N. L. \& Kpee, G. G. (2018). Knowledge management for sustainable early childhood education development: a strategy for revolutionalising early childhood education in Nigeria. World Educators Forum, 10 (1), 1-12.

Obilo, I. P. \&Opara-Onukwugha, M. (2008). Roles of entrepreneurship educaiton in the 21st century Nigeria. In Okeke, Obunadike, \& Ugbagir (eds), Entrepreneurship education in the 21st century Nigeria. Onitsha: West and Solomon Publishing Coy Ltd.

Ofoegbu, F. I., \& Alonge, H. O. (2016). Internally Generated Revenue (IGR) and Effectiveness of University Administration in Nigeria. Journal of Education and Learning, 5(2), 1-8.

Ofor-Douglas, S. (2019). Chapter Twenty: Management of Covid-19 in Nigerian Universities. In Ekong, A. O., Usen, S. M. \& Essien, E. N (Eds), Developing Alternative Teaching Continuity Plans to Move Classrooms Online at Covid-19 Era in Nigeria (pp. 1-14).

Ojo, O. O., \& Abibu, A. B. (2018). Re-Orientation of Moral Value System in Nigeria: The Roles of Women as Change Agents. Journal of research in education and society, 9(3), 1-5.

Okafor, F. C. (1981). Philosophy of education and third world perspective.

Okobia, F. N., Okafor, M. I., \& Osajie, J. N. (2016). Reactivating Nigerian norms and values through religious studies for national transformation. OGIRISI: A New Journal of African Studies, 12, 151-168.

Olasehinde-Williams, O. (2018). Education in Nigeria for Value Re-Orientation and National Development. Nigerian Jpurnal of Social Stidies, XXI (1), 125-143.

Olayanju, O. J. (2014). Historical analysis of the implementation of teacher education policy in Nigeria: 1896-2013. International Journal of Special and General Education, 3, 131-154.
Oluwagbohunmi, M. F. (2013). Enhancing quality education for transformation of character and values through social studies education. Arabian Journal of Business and Management Review (Nigerian Chapter) Vol, 1(4).

Omoregbe, J. I. (1989). Ethics a systematic and historical study.

Orji, F. O., \& Umoren, F. J. (2016). Role of educational administration in value reorientation: Implication for sustainable national development. Journal of Reflective Thinking, 3(1), 92-103.

Osisioma, B. C. (2012). Nigeria's transformation agenda: The management and leadership challenges. Lead paper, South-East Zonal Management Summit. Nnamdi Azikiwe University, Awka.

Paul, L. (2020). The flying Classroom: Study trips in Education for Sustainable Development.

Roa, B. B. (2003). Values in higher education. Tilale JBG Eduaction, Society and Development. National and International Perspectives; New Delhi, APH Publishing Corporation.

Robert-Okah, I., \& Daminabo, D. A. F. (2014). Bridging the Gap in Quality Entrepreneurship Education in Tertiary Institutions in Rvers Sate: A Paradigm for Mmeeting MDGs through Jopb Vreation. Reiko International Joutnal ot Socila and Economic Research, 7(21), 112-125.

Rokeach, M. (1973). The nature of human values. Free press.

Santhi, S. (2016). Need quality education in the 21 century-role of the secondary education teachers. International Education \& Research Journal [IERJ], 3 (2), 25-28.

Taiwo, S. C. (2012). Financing University Education in Nigeria: Implications for Staff and Students' Management in the Southwest GeoPolitical Zone. Journal of Education and Policy Review, 4, 19-30.

Tienhaara, P., Lyytinen, A., \& Kivistö, J. (2016). Management Education in Transformation- 
Current Challenges and Future Perspectives. University of Tampere.

Tuulik, K., Õunapuu, T., Kuimet, K., \& Titov, E. (2016). Rokeach's instrumental and terminal values as descriptors of modern organisation values. International Journal of Organizational Leadership, 5, 151-161.

Uko, E. S., \& Nnaji, E. S. (2016). Managing tertiary institutions for the promotion of lifelong learning in cross river state, Nigeria. Global Journal of Educational Research, 15(1), 41-47.

Unamba, E. C., Izuagba, N. J., \& Ogbonnaya, C. N. (2016). Use of flipped classroom model to enhance engagement and promote active learning among primary school pupils in algebra. Journal of Teacher Perspective, 11(1). 